STUDIA HISTORICA GEDANENSIA

TOM X (2019)

\author{
Karol Sanojca \\ (Wydział Nauk Historycznych i Pedagogicznych, \\ Uniwersytet Wrocławski)
}

\title{
Edukacja historyczna w gimnazjach ukraińskich w okresie Drugiej Rzeczypospolitej
}

Edukacja historyczna to nie tylko przekaz informacji, ale skomplikowany system oddziaływań na sferę postaw i poglądów. Odgrywała ona szczególną rolę społeczną, gdy w okresie międzywojennym, z powodu obecności w granicach państwa polskiego około pięciomilionowej mniejszości ukraińskiej, kwestią niezmiernie ważną i delikatną było ułożenie wzajemnych relacji. Ścierały się tu różne spojrzenia i wizje, zarówno polskie, jak i ukraińskie, różne też proponowano narzędzia i sposoby postępowania. Obok planów zakładających pełną asymilację i akulturację mniejszości ukraińskiej obecne były postulaty przyznania jej szerokich uprawnień. Przez cały okres dwudziestolecia szkoła pozostawała znakomitym probierzem stosunków polsko-ukraińskich, a jednocześnie miejscem pozwalającym oddziaływać wychowawczo na młode pokolenie i pracować na rzecz wzajemnego zrozumienia. Równocześnie jednak teren szkoły świetnie nadawał się do prowadzenia działalności mającej na celu niweczenie tych zabiegów. Te dwie sprzeczne tendencje najwyraźniej można zaobserwować w placówkach, w których młodzież ukraińska pobierała naukę, a więc przede wszystkim gimnazjach $\mathrm{z}$ ukraińskim językiem nauczania.

W okresie międzywojennym ukraińskie szkoły średnie istniały przede wszystkim na obszarze województw lwowskiego, stanisławowskiego i tarnopolskiego. Na Polesiu nie było szkół z ukraińskim językiem nauczania, a na Wołyniu działały jedynie dwie szkoły prywatne - koedukacyjna w Krzemieńcu i męska w Łucku. Trzy pierwsze wymienione województwa tworzyły obszar Kuratorium Okręgu Szkolnego Lwowskiego, gdzie wśród 65 gimnazjów państwowych była nieliczna grupa placówek z ukraińskim językiem wykładowym. Należały do nich gimnazja państwowe: we Lwowie (zakład główny i filia), Przemyślu, Kołomyi, Stanisławowie i Tarnopolu (do 1930 r.). W Stryju i Buczaczu istniały klasy równoległe z językiem wykładowym polskim i ukraińskim, a tylko w szkole w Brzeżanach 
klasy utrakwistyczne ${ }^{1}$. Dodatkowo ukraińskie gimnazja prywatne funkcjonowały we Lwowie, Czortkowie, Drohobyczu, Horodence, Jaworowie, Kołomyi, Przemyślu, Rohatynie, Samborze, Stanisławowie, Stryju, Tarnopolu i Złoczowie. Prowadzone były one głównie przez Ukraińskie Towarzystwo Pedagogiczne „Ridna Szkoła”, a poza tym przez siostry bazylianki oraz Ukraiński Instytut dla Dziewcząt. Łącznie na terenie kuratorium lwowskiego funkcjonowało osiem średnich szkół państwowych i szesnaście prywatnych z ukraińskim językiem nauczania². Uczęszczało do nich ogółem około pięciu tysięcy uczniów tej narodowości, a dodatkowo około $1-1,5$ tysiąca pobierało naukę w szkołach polskich ${ }^{3}$. Warto też dodać, że w kolejnych pięciu polskich gimnazjach język ukraiński był przedmiotem obowiązkowym, a w niektórych można było się go uczyć jako nadobowiązkowego.

Gimnazja ukraińskie utworzone zostały w zdecydowanej większości u schyłku XIX w. lub w pierwszych latach wieku XX, a ich powstawanie często odbywało się $\mathrm{w}$ atmosferze polsko-ukraińskiego konfliktu narodowościowego ${ }^{4}$. W czasach istnienia państwa austro-węgierskiego zarówno Ukraińcy, jak i Polacy byli podporządkowani władzy w Wiedniu, język niemiecki był językiem państwowym, a polski i ukraiński - równorzędnymi językami krajowymi. Natomiast edukacja historyczna w dużej mierze miała służyć podtrzymaniu spoistości monarchii habsburskiej. Powstanie państwa polskiego i toczona u jego początków wojna polsko-ukraińska dodatkowo skomplikowały sytuację narodowościową w byłej Galicji, zwłaszcza że po roku 1918 język polski zyskał status państwowego, ośrodek decyzyjny z Wiednia przeniósł się do Warszawy, a przed szkołą postawiono nowe zadania. Nie bez znaczenia był też fakt, że „stołeczny” Lwów został zdegradowany do wprawdzie dużego, ale jednak prowincjonalnego ośrodka.

Wszystkie szkoły państwowe, bez względu na język wykładowy, objęto ministerialnymi programami nauczania i korzystały z podręczników znajdujących się na liście książek dopuszczonych do użytku szkolnego ${ }^{5}$. Korzyści wynikające z przyznawania szkołom prywatnym praw szkół państwowych powodowały, że także

1 Ludwik Eckert, Uwagi i notatki o szkolnictwie i polityce szkolnej, Archiwum Polskiej Akademii Nauk (Arch. PAN) Materiały Ludwika Eckerta III-180, 228, k. 66-68.

2 Lista gimnazjów ukraińskich 1918-1939, Центральний Державний Історичний Архів України у Львові (CDIAUL), Kuratorium Okręgu Szkolnego Lwowskiego (KOSLw.) f. 179, op. 3, spr. 68, k. 1-77.

Arch. PAN, Eckert, Uwagi i notatki, sygn. 227, k. 95.

4 Jarosław Moklak, „Ukraińska elita polityczna Galicji i kwestia szkolnictwa narodowego na początku XX wieku”, Київський національний університет імені Тараса Шевченка. Українознавчий альманах 14 (2013): 234-237; Maria Stinia, „Sprawy szkolnictwa ukraińskiego na łamach »Muzeum « w latach 1885-1914", w Stosunki polsko-ukrainskie w szkolnej edukacji historycznej od XIX do XXI wieku, red. Hanna Wójcik-Łagan (Kielce: Kieleckie Towarzystwo Naukowe; Akademia Świętokrzyska im. Jana Kochanowskiego, 2005), 115-124.

5 Odrębny podręcznik do historii dla średnich szkół ukraińskich nigdy nie wyszedł poza fazę projektową. Nawet przygotowywane koncepcje zmodyfikowanych programów nauczania nie zostały wprowadzone do użytku. Zob. szerzej Karol Sanojca, Relacje polsko-ukraińskie w szkolnictwie 
te placówki decydowały się realizować program ministerialny i używały oficjalnych podręczników ${ }^{6}$. Ponadto nauka historii jako przedmiotu szkolnego musiała być prowadzona w języku polskim. Wszystko to razem dawało władzom oświatowym narzędzia oddziaływania na młodzież ukraińską. W efekcie kształtowanie jej świadomości historycznej odbywało się na kilku płaszczyznach - na lekcjach dominowały elementy oficjalnej edukacji historycznej, jednak część wiedzy o przeszłości młodzi Ukraińcy zdobywali poza terenem szkoły, ze źródeł o charakterze nieoficjalnym, a nawet nielegalnym. Dlatego też rozlegały się głosy wskazujące nie bez racji, że szkoła powinna w jak największym stopniu uwzględniać zagadnienia $\mathrm{z}$ historii narodu ukraińskiego, co pozwalałoby mieć kontrolę nad przekazem informacji i nakierowywać narrację na podkreślanie wspólnej przeszłości, a także uzasadniać pożytki z pokojowego współistnienia obu narodowości.

Ministerialny program nauczania, a w konsekwencji także podręczniki szkolne, zawierały oczywiście treści dotyczące przeszłości ziem ukraińskich. Pojawiały się tam więc na przykład kwestie dotyczące osadnictwa w początkach epoki nowożytnej, dziejów Kozaczyzny i jej znaczenia dla kształtowania się zrębów ukraińskiej tożsamości narodowej. Mowa była także o unii lubelskiej i jej pozytywnych konsekwencjach dla życia narodowego Ukraińców, o okolicznościach i znaczeniu zawarcia unii brzeskiej. Przedstawiano przebieg wojen kozackich (oczywiście ze szczególnym uwzględnieniem powstania Chmielnickiego), historię konfliktu między Rosją a Rzeczpospolitą o Ukrainę w XVII w., przyczyny powstań chłopskich w XVIII w. (koliszczyzna), a także prześladowania Polaków i Ukraińców pod zaborem rosyjskim. Wśród wydarzeń XX w. uwzględniano próbę utworzenia niepodległego państwa ukraińskiego i walki o Lwów w $1918 \mathrm{r}$. W towarzyszących tym ostatnim kwestiom komentarzach nie eksponowano sprzeczności, ale raczej potrzebę zgodnego współżycia obu narodów. Podobna idea przyświecała prezentacji zagadnień współczesnych, gdzie stosunki polsko-ukraińskie przedstawiano w sposób wyidealizowany”.

Władze szkolne starały się w praktyce stosować jednolite kryteria dla szkół polskich i ukraińskich, a przy ocenie stanu edukacji historycznej zwracać uwagę nie tyle na specyfikę narodowościową, ile na rzeczywiste efekty kształcenia. Można to dobrze prześledzić na przykładzie ukraińskiego gimnazjum w Kołomyi

państwowym poludniowo-wschodnich województw Drugiej Rzeczypospolitej (Kraków: Towarzystwo Wydawnicze „Historia Iagellonica” 2013), 259-264, 273-274.

6 Spis podręczników obowiązujących w Prywatnym Gimnazjum Koedukacyjnym UTP „Ridna Szkoła” im. M. Szaszkiewicza z ukraińskim językiem nauczania w Czortkowie w roku szkolnym 1938/1939, CDIAUL, KOSLw. f. 179, op. 3, spr. 232, k. 102; Spis podręczników używanych w gimnazjum i liceum (w Gimnazjum koedukacyjnym im. Iwana Franki z ukraińskim językiem nauczania w Drohobyczu w 1939 r.). CDIAUL, KOSLw. f. 179, op. 3, spr. 232, k. 10.

Przykładem takiej narracji może być fragment podręcznika Jana Dąbrowskiego: „Mniejszości narodowe mają szkoły zarówno powszechne jak średnie, w których językiem wykładowym jest ich język ojczysty”. Jan Dąbrowski, Wiadomości z dziejów Polski, 3 (Lwów: Nakład i własność K.S. Jakubowskiego, 1928), 138. 
prowadzonego przez „Ridną Szkołę”. I tak wizytator kuratoryjny Stanisław Pająk w 1928 r., po przeprowadzeniu kontroli tego gimnazjum stwierdzał: „Nauka geografii oraz historii w rękach nauczyciela Dymitra Szumeja przedstawia wyniki zupełnie zadowalające". Gdy w roku następnym szkołę wizytował Roman Koestlich wnioski nie były już tak pozytywne: „Nauczyciel historii w klasie siódmej ogranicza się do kontrolowania pracy domowej przez odpytywanie w chronologicznym porządku tych faktów, które podano na poprzedniej lekcji w formie wykładu, nauczyciel nie usiłuje kształcić myślenia historycznego. Na lekcji nauki o Polsce współczesnej okazało się, że niektóre pojęcia z nauki o państwie nie są uczennicom dość jasne, mają one też wielkie braki z historii Polski"9. Kontrolujący placówkę w 1932 r. kolejny wizytator, Ludwik Tuleja, poziom nauczania historii oceniał następująco: „Nauczycielka w kl. I i IV nie opanowała jeszcze całkowicie metody. Braki te należy usunąć przez odwiedzanie lekcji wybitnych nauczycieli. Rezultaty pracy w kl. I dobre, w kl. IV słabe. Nauczyciel w kl. VII i VIII opiera nauczanie na wykładzie i używaniu mapy. Na lekcjach swych wykazał wiele spokoju i równowagi. Uczennice kl. VII orientują się w materiale bardzo słabo. Wiadomości kl. VIII są dodatnie"10. Jeszcze bardziej dokładny przebieg miała wizytacja przeprowadzona przez tego samego wizytatora rok później: „Nauczyciele historii nie posiadają jeszcze długiej praktyki, lecz wywiązują się na ogół nieźle ze swego zadania. Dodatnio przedstawiały się lekcje historii w kl. II i V. W kl. II mówiono o czasach Jana III Sobieskiego. W rozmowach z uczennicami posługiwała się nauczycielka mapą i obrazami. Badałem wiadomości z przerobionego materiału. Odpowiedzi uczennic były zupełnie dobre. Na lekcji historii w kl. V omówiono testament Bolesława Krzywoustego, czasy Henryka I, Bolesława Wstydliwego i Leszka Czarnego. Na moje żądanie badała nauczycielka wiadomości uczennic o wyprawach krzyżowych. Uczennice wykazały wiele pozytywnych wiadomości, znają z tekstów źródłowych ustępy, odnoszące się do omawianych czasów. Datami nie należy szpikować podawanych wiadomości [do dziś aktualny postulat! - K.S.]. W kl. VII badał nauczyciel wiadomości z przerobionego materiału »Rewolucja lutowa we Francji« i zaznajomił uczennice z przebiegiem rewolucji w Austrii w r. 1848. Nauczyciel oparł wykład na podręczniku Nankego, a z tekstów polecił odczytać manifest cesarza Ferdynanda I. Wiadomości uczennic były słabe, lecz można je ocenić jako na ogół dostateczne" ${ }^{11}$. Dość podobna była ocena stanu nauczania w 1934 r. (szkołę wizytował wówczas Stanisław Szediwy): „Historia: Wiadomości uczennic(ów) w kl. I na ogół dostateczne - wiadomości dawniejsze mniej pewne, nowsze zaś dobre. W pozostałych klasach stan dostateczny - metoda

$8 \quad$ Sprawozdania z wizytacji prywatnego gimnazjum żeńskiego Ukraińskiego Towarzystwa Pedagogicznego „Ridna Szkoła” w Kołomyi, CDIAL, KOSLw. f. 179, op. 3, spr. 795, k. 3.

9 Sprawozdania z wizytacji, k. 9.

$10 \quad$ Ibidem, k. 50.

11 Ibidem, k. 64. 
pracy nauczycielki na ogół bez usterek, egzekutywa dobra"12. Natomiast dwa lata później po hospitacji lekcji historii wizytator Jerzy Polański ocenił: „Nauczycielka (p. Perejma) opanowała metody nauczania i budzi samodzielność pracy młodzieży, dobrze organizuje pracę domową uczennic(ów) i starannie obmyśla plany lekcyjne. Stan nauki dobry. Należy jednakowoż lepiej wykorzystywać pomoce naukowe, przede wszystkim stale używać map i atlasów. W kl. VII nauczycielka poświęca prawie całą godzinę w tygodniu na omawianie prac. W przyszłości należałoby na ten cel poświęcać właściwy wymiar czasu i to przeważnie w klasie najwyższej. Nadto zaleca się przy omawianiu pracy domowej dążyć do celowej selekcji wybranych do omawiania spraw, jak też do ostrożnego dobierania referentów spośród uczennic. W kl. VI nauczyciel (p. Ilnicki) posługuje się dawnymi, konserwatywnymi werbalnymi metodami, uczniowie reprodukują starą lekcję na podstawie podręcznika i nie dopatrują się w dzisiejszych zagadnień i związków nadto podpowiadają bez skrupułów. Tempo nieporywające"13.

Choć zakres programowy kształcenia historycznego miał obejmować wszystkich uczniów bez względu na ich narodowość, istniała jednak specyfika działań edukacyjnych wobec młodzieży mniejszości, uwzględniająca ich historię i tradycje. Przejawiała się ona głównie w zajęciach pozalekcyjnych i obrzędowości szkolnej. Wiele składników wyznaczających ukraińską tożsamość narodową akceptowanych było przez władze bez większych zastrzeżeń. Dotyczyło to przede wszystkim sfery kultury. Na przykład w 1921 r. szczególnie uroczyście obchodzono 60. rocznice śmierci Tarasa Szewczenki (1814-1861) ${ }^{14}$. Dzień 10 marca był wolny od nauki w szkołach średnich z ukraińskim językiem wykładowym - przeznaczono go na odczyty naukowe, deklamacje lub uroczyste akademie. Ponadto we wszystkich szkołach średnich, do których uczęszczała w znacznej liczbie młodzież ukraińska, zgodnie z zarządzeniem delegata MWRiOP Stanisława Sobińskiego należało „dać możność uczczenia rocznicy śmierci poety w sposób, który dyrekcje porozumiawszy się z członkami Grona narodowości ruskiej, uznają za odpowiednie”. Zadaniem nauczycieli było omówić jego twórczość i podkreślić znaczenie dla literatury ukraińskiej. Należało też „dołożyć wszelkich starań, aby obchód ten był nacechowany podniosłością, a wolnym od wszelkich rozdźwięków, nastrojem odpowiadającym godnie uroczystości chwili”"15. Dla polskich władz oświatowych rocznica ta miała się stać jednym z czynników odbudowywania dobrosąsiedzkich polsko-ukraińskich więzi. Obchody „szewczenkowskie” organizowano również w kolejnych latach. Podobnie celebrowano jubileusze związane z życiem i twórczością Iwana Franki.

\footnotetext{
12 Ibidem, k. 123

$13 \quad$ Ibidem, k. 161.

14 Stanisław Sobiński, Szkolnictwo w Małopolsce Wschodniej pod względem stosunków narodowych (Lwów: Nakładem Wydawnictwa Książek Szkolnych, 1921), 21.

15 Zakłady nauczania lwowskiego okręgu szkolnego, Державний Архів Львівської Області (DALO) f. 1262, op. 58, spr. 348, k. 31.
} 
Specyficznym narzędziem edukacji historycznej były też wzorce i ideały uosabiane przez patronów szkół - najczęściej przedstawicieli kultury bądź ludzi Kościoła. W placówkach ukraińskich prowadzonych przez Towarzystwo Pedagogiczne „Ridna Szkoła” pojawiały się w tej roli przede wszystkim osoby poświadczające swą działalnością żywotność narodu ukraińskiego. Gimnazjum koedukacyjne w Jaworowie miało za patrona Osipa Makoweja (1867-1925) urodzonego w tym mieście poetę, publicystę, dyrektora seminarium nauczycielskiego w Zaleszczykach. Jeden z pierwszych poetów ukraińskich Markian Szaszkiewicz (1811-1843) patronował szkołom powszechnym we Lwowie i Przemyślu ${ }^{16}$ oraz gimnazjum w Czortkowie, a Taras Szewczenko (1814-1861) został patronem seminarium nauczycielskiego we Lwowie i gimnazjum w Horodence. Władze Kościoła greckokatolickiego ustanowiły dla młodzieży swojego wyznania odpowiednika św. Stanisława Kostki - patrona polskiej młodzieży katolickiej. Stał się nim św. Jozafat (ok. 1580-1623), arcybiskup połocki. W roku 1926 ordynariat biskupi w Stanisławowie ustanowił go patronem młodzieży grekokatolickiej na obszarze diecezji, nakazując uroczystość jemu poświęconą obchodzić 25 listopada. W tym dniu w szkołach z językiem wykładowym ukraińskim oraz w szkołach utrakwistycznych młodzież obu obrządków katolickich zwolniona była $\mathrm{z}$ nauki ${ }^{17}$. Postać świętego od początku przyjęły za swego patrona szkoły prowadzone przez zakon bazylianów (gimnazjum w Buczaczu) i bazylianek (seminarium nauczycielskie we Lwowie).

Dla młodzieży ukraińskiej ważnymi świętami były rocznice wydarzeń z okresu budowy niezależnej państwowości ukraińskiej. W pierwszy dzień listopada obchodzono rocznicę proklamowania niepodległości przez Zachodnioukraińską Republikę Ludową, 22 stycznia aktu zjednoczenia ziem ukraińskich, a 29 stycznia czczono pamięć poległych w bitwie pod Krutami, będącej symbolem bohaterstwa w walce o suwerenną Ukrainę. Po zamordowaniu w Paryżu w 1926 r. Semena Petlury honorowano także jego osobę ${ }^{18}$. Choć formalnie nie obchodzono tych świąt w szkole, to władze tolerowały udział uczniów w nabożeństwach i zgromadzeniach organizowanych przez ukraińskie organizacje społeczne. Nie zgłaszały też sprzeciwu wobec instytucjonalnych form uczestnictwa w niektórych świętach ukraińskich. Na przykład chór szkolny uczennic prywatnego gimnazjum sióstr bazylianek we Lwowie w roku szkolnym 1928/1929 wystąpił na trzech koncertach: ku czci metropolity Szeptyckiego, w dniu święta „Proswity” oraz w 68. rocznicę śmierci

16 W Przemyślu do przedwojennej tradycji powrócono w roku 1991 nadając imię M. Szaszkiewicza mieszczącemu się w tym samym budynku Zespołowi Szkół Ogólnokształcących z ukraińskim językiem nauczania.

17 Okólnik z 15 listopada 1926 roku, „Dziennik Urzędowy Kuratorium Okręgu Szkolnego Lwowskiego" 1926, 514.

18 Jak zauważał A. Bocheński postacie bohaterów pełnią szczególnie ważną rolę dla „narodów poszukujących swojej tożsamości”. Aleksander Bocheński, „Problem polityczny Ziemi Czerwieńskiej”, w Aleksander Bocheński, Stanisław Łoś, Włodzimierz Bączkowski, Problem polsko-ukraiński w Ziemi Czerwieńskiej (Warszawa: „Polityka”, 1938), 27. 
Tarasa Szewczenki ${ }^{19}$. Gimnazjaliści brali również aktywny udział w akcjach nielegalnych - sypania kopców i upamiętniania miejsc spoczynku żołnierzy ukraińskich walczących w różnych formacjach i na różnych frontach pierwszej wojny światowej ${ }^{20}$. Sięgano też do dawniejszych kozackich tradycji, czcząc w ten sam sposób uczestników bitwy pod Beresteczkiem.

Istotnym elementem szkolnej edukacji historycznej były obchody świąt państwowych. Uczestniczyli w nich uczniowie gimnazjów ukraińskich, choć pojawiały się incydenty świadczące o panujących wśród nich nastrojach. Zdarzało się manifestowanie niechętnych postaw, które przybierało różne formy - od drobnych symbolicznych gestów do bojkotu, a nawet czynnego zakłócania przebiegu uroczystości. W 1928 r. uczniowie państwowego gimnazjum ukraińskiego w Stanisławowie odmówili uczestniczenia $\mathrm{w}$ uroczystym pochodzie ulicami miasta z okazji święta Konstytucji 3 maja. Postępek ten został zinterpretowany przez władze oświatowe jako akt o charakterze antypaństwowym, dlatego podjęto decyzję o natychmiastowej likwidacji pięciu wyższych klas tego gimnazjum. W konsekwencji około 200 uczniów na kilka tygodni przed końcem roku szkolnego zostało de facto usuniętych ze szkoły. Sprawa dotarła na forum sejmu, gdzie za młodzieżą ze Stanisławowa ujęli się posłowie Ukraińskiej Reprezentacji Parlamentarnej²1. Posłanka Milena Rudnicka starała się przerzucić odpowiedzialność na polskie społeczeństwo, przywołując wydarzenia z innych podobnych uroczystości. Mianowicie, właśnie w Stanisławowie, podczas obchodów święta niepodległości w 1927 r. Polacy mieli „obrzucić obelgami” uczniów ukraińskich defilujących przed miejscowym grobem Nieznanego Żołnierza. Do podobnego zajścia miało dojść także w Tarnopolu w trakcie pochodu w dniu imienin Marszałka. W tej sytuacji zachowanie stanisławowskich ukraińskich gimnazjalistów miało być tylko reakcją na postępowanie Polaków ${ }^{22}$. W późniejszej dyskusji, która odbyła się na forum Komisji Oświatowej i sesji plenarnej sejmu dość zgodnie uznawano, że kara była niewspółmierna do winy ${ }^{23}$. Podobne jak w Stanisławowie zachowania ukraińskich uczniów miewały miejsce podczas świąt państwowych również w innych latach

19 Protokół rady pedagogicznej prywatnego gimnazjum żeńskiego ss. bazylianek we Lwowie w roku szkolnym 1928/1929. CDIAUL, KOSLw. f. 179, op. 3, spr. 46, k. 66.

${ }^{20}$ W 1933 r. w Rohatynie złożono wieńce na grobach żołnierzy ukraińskich, a jeden z wieńców miał pochodzić od uczniów miejscowego gimnazjum. Roman Wysocki, Organizacja Ukraińskich Nacjonalistów w Polsce w latach 1929-1939. Geneza, struktura, program, ideologia (Lublin: Wydawnictwo Uniwersytetu Marii Curie-Skłodowskiej, 2003), 235.

${ }^{21}$ Interpelacja posłów Klubu Ukraińskiego do p. Ministra Wyznań Religijnych i Oświecenia Publicznego w sprawie zamknięcia 5 wyższych klas państwowego gimnazjum ukraińskiego w Stanisławowie. Sprawozdanie stenograficzne Sejmu z 15 maja 1928 r., VIII/21.

22 Wniosek Klubu Ukraińskiego w sprawie zamknięcia 5 klas gimnazjum ukraińskiego w Stanisławowie: Rudnicka-Łysiak. Sprawozdanie stenograficzne Sejmu z 29 maja 1928 r., XI/57.

23 „Ilustrowany Kurier Codzienny” z 11 czerwca 1928 r., s. 10; Mirosław Szumiło, Ukraińska Reprezentacja Parlamentarna w Sejmie i Senacie RP (1928-1939) (Warszawa: Wydawnictwo Neriton, 2007), 98. 
i w innych miejscowościach. Na przykład w styczniu 1929 r., przy okazji imienin prezydenta Ignacego Mościckiego młodzież ukraińskiego gimnazjum państwowego w Tarnopolu planowała bojkot nabożeństwa ku czci solenizanta. Zamierzały się do niego przyłączyć także uczennice gimnazjum „Ridnej Szkoły”. Akcji tej zapobiegła jednak rozsądna interwencja ukraińskich nauczycieli ${ }^{24}$.

Uczniowie unikali też aktywnego uczestnictwa w świętach państwowych, stosując różne formy obstrukcji: fałszując bądź powstrzymując się od wykonywania polskich pieśni patriotycznych czy odmawiając napisania okolicznościowego referatu ${ }^{25}$. Jeszcze innym sposobem wyrażania negatywnego stosunku do obrzędowości państwowej były próby czynnego zakłócenia przebiegu święta (na przykład poprzez użycie gazów łzawiących) lub uniemożliwienie jego przeprowadzenia zgodnie z planem. Ilustruje to incydent, jaki miał miejsce w II ukraińskim żeńskim seminarium nauczycielskim we Lwowie w 1934 r. W nocy z 31 stycznia na 1 lutego dokonano tam włamania do szkoły. Zniszczono godła państwowe, podarte zostały portrety prezydenta Mościckiego, poprzecinano też struny skrzypiec. Miało to przeszkodzić w urządzeniu następnego dnia poranka z okazji imienin prezydenta ${ }^{26}$.

Edukacja historyczna młodzieży ukraińskiej nie odbywała się wyłącznie w szkole, a jej wiedzę o przeszłości kształtowały różne czynniki. Niebagatelne znaczenie miał silny nurt narodowy reprezentowany przez legalne i nielegalne organizacje, a także Kościół greckokatolicki. Kultywowanie pamięci o własnej przeszłości i tradycjach stało się ważnym elementem demonstrowania narodowej odrębności. Inspiracje i wzorce czerpano także z działalności polskich sił niepodległościowych i aktywności polskiej młodzieży w XIX w. Podobnie wykorzystywano istniejący w szkole polskiej kult bohaterów narodowych i wieszczów, który starano się przekładać na realia ukraińskie ${ }^{27}$. Osobnym, acz trudnym do precyzyjnego zdiagnozowania problemem pozostaje określenie roli, jaką edukacja historyczna w gimnazjach ukraińskich odegrała w kształtowaniu elity zdolnej zaakceptować istniejący porządek prawny i funkcjonowanie w ramach ówczesnego państwa polskiego.

24 Никифор Гірняк, „Моя праця в “Рідній Школі” в 1922-1939 і 1941-1944”, w Шляхами Золотого Поділля. Реліональний історично-мемуарний збірник Тернопільщини 1, Філадельфія: „Тернопільщина” 1983, 164-165.

25 Zorganizowaną akcję tego typu przygotowywał OUN w związku z obchodami 15. rocznicy powstania państwa polskiego. Inspektor szkolny w Tarnopolu otrzymał informacje od starostwa o agitacji wśród uczniów i namawianiu ich, by uroczystościom przeciwdziałać, lub w ostateczności starać się, by wypadły one jak najgorzej. Sugerowano uczniom na przykład jąkanie się w czasie deklamacji, czy fałszowanie w trakcie śpiewów chóralnych. Akcję tę mieli przeprowadzić na terenie szkół członkowie „Junactwa”. Doniesienia inspektorów szkolnych z terenu województwa tarnopolskiego, CDIAUL, KOSLw. f. 179, op. 1, spr. 485, k. 59-61.

${ }_{26}$ DALO, Prokuratura Sądu Okręgowego we Lwowie, f. 139, op. 9, spr. 1156, k. 1-13.

27 Wysocki, Organizacja Ukraińskich Nacjonalistów, 237. 


\title{
Karol Sanojca \\ Historical education in Ukraninian gymnasiums during the Second Polish Republic
}

\begin{abstract}
Summary
There were more than twenty state and private gymnasiums with the Ukrainian language of instruction. Shaping the historical consciousness of young Ukrainians happened on on several levels. In the history lessons, which according to statutory provisions had to be kept in Polish, polonocentric vision of history was presented, taking into account to a certain extent however, the past of Ukrainian lands. A specific tool of historical education were also school patrons with ideals and standards they represented. Ukrainian youth expressed a clear reluctance towards school celebration of Polish national holidays. On the other hand, anniversaries of events from the period of building the independence of Ukrainian statehood (1918-1921) were important for them.
\end{abstract}

